Western University

Scholarship@Western

Business Publications

Business (Richard Ivey School of Business)

2010

\title{
A Social Movement Perspective on Finance: How Socially Responsible Investment Mattered
}

Diane-Laure Arjaliès

Ivey Business School, darjalies@ivey.ca

Follow this and additional works at: https://ir.lib.uwo.ca/iveypub

Part of the Business Administration, Management, and Operations Commons, Business Law, Public Responsibility, and Ethics Commons, and the Finance and Financial Management Commons

Citation of this paper:

Arjaliès, D-L. (2010). A Social Movement Perspective on Finance: How Socially Responsible Investment Mattered, Journal of Business Ethics, 92: 57-78. 


\section{A Social Movement Perspective on Finance: How Socially Responsible Investment Mattered}

Diane-Laure Arjaliès

Author's details: Diane-Laure Arjaliès is a Ph.D. candidate at ESSEC Business School (Cergy, France) and a research associate at Ecole Polytechnique (Palaiseau, France).

Contact information:

Département d'Economie

École Polytechnique,

9I 128 Palaiseau Cedex,

FRANCE

Tel. : +33(0) I 69333333

Email: diane-laure.arjalies@essec.edu

ABSTRACT. This article discusses how social movements can influence economic systems. Employing a political-cultural approach to markets, it purports that 'compromise-movements' can help change existing institutions by proposing new ones. This article argues in favor of the role of social movements in reforming economic institutions. More precisely, Socially Responsible Investment (SRI) movements can help bring SRI concerns into financial institutions. A study of how the French Socially Responsible Investment (SRI) movement has been able to change entrenched institutional logics of the French asset management sector provides wide-ranging support for these arguments. Empirical findings are drawn from a longitudinal case study (1997-2009), based on participative observation, interviews and documentary evidence. Implications for research on Social Movements, Institutional Change and Socially Responsible Investment are outlined. Lastly, the article provides practitioners with some theoretical keys to understand the pros and cons of 'SRI labels'.

KEY WORDS: Framing, France, Institutional Change, Organizational field, Social Movements, Socially Responsible Investment (SRI) 


\section{Introduction}

"Socially Responsible Investment has been so successful that it has died." - Social Rating Agency, Manager, 2007

Over the past decades, modern capitalist societies have been said to have undergone a legitimacy crisis whereby support for both government and economy has been systematically eroded (Habermas, 1976; Barker, 1990; Habermas, 2008). Facing this legitimacy crisis, collective mobilizations - from environmental to human rights militants and shareholder activism - have endeavored to change economic and political institutions. The recent 2008 economic crisis and the collapse of some of the most powerful global financial institutions have escalated this demand for social change from protest movements to states. Thus, the Economic Nobel Prize winner, Paul Krugman, declared: 'The people who assured us that markets work; that the private pursuit of profit always leads to a good result have been rather massively wrong.' (Reuter News, 14/10/2008). These recent developments have contributed to transforming the 'movement society' (Meyer and Tarrow, 1998) from an abstract concept to a concrete and real trigger for change. As social movements describe how groups of actors form coalitions to create or resist institutional arrangements (Zald and McCarthy, 1977), their project according to Habermas must not be understood as a utopian and revolutionary alternative to liberal market societies (Habermas, 1996, 1998).

The new social movements which have developed over the past decades are collective and rational responses to the legitimacy crisis of post-industrial societies (Canel, 1997). Far from rejecting economic rationality, these new social movements are expected to play a prominent role in reforming the current economic and political institutions, which critically need change to maintain democracy (Habermas, 2008). With this in mind, the central question addressed in this article is the following: to what extent and under what conditions can these new social movements change economic institutions? Drawing on a political-cultural approach to the markets - 'Markets as Politics' (Fligstein, 1996) - this article posits that economic institutions are social constructions whose form and maintenance follow a political project. In this sense, changing economic institutions cannot be separated from changing political institutions (Habermas, 1996, 1998, 2008).

The new social movement theory initially developed in Europe to explain the emergence of new social movements in the 1960s which did not seem to fit a model of Marxian class conflict 
(Touraine, 1969; Habermas, 1976). These referred to various social movements such as regional movements (e.g. the Basque country), Gay Movements and the Women's Liberation Movement. Over the past years, a new generation of social movements has appeared. This includes movements such as recycling militants (Lounsbury et al., 2003), shareholder activism (Davis and Thompson, 1994) and civil society organizations (Sjostrom, 2007). Notably, these movements differ from previous social movements by their focus on economic institutions, from which they originate (e.g. shareholder activism). These new social movements strive to restore social responsibility within economic institutions: they are known as Corporate Social Responsibility (CSR) movements (Gendron and Turcotte, 2007; Scherer and Palazzo, 2007). CSR movements group the four characteristics of the new social movements, namely: a collective identity, the sharing of individual resources for a common purpose, a will to change existing institutions and the search for a new general orientation for society (Touraine, 1969; Zald and Berger, 1978). The Socially Responsible Investment (SRI) movement, which aims at bringing social responsibility to the asset management sector, is one of them (Gendron and Turcotte, 2007). While CSR movements aim to transform economic institutions, the SRI movement focuses on financial institutions.

Although historically the SRI movement appeared as a marginalized movement composed of ethical activists, it has achieved in the last few years a rise in influence and credibility. The launch in 2005 by the former United Nations Secretary-General, Kofi Annan, of the Principles for Responsible Investment (PRI) illustrates this trend: 'By acting collectively on the basis of these principles for responsible investment, we can help protect all the world's precious assets.' (Kofi Annan, 2005) The goal of the SRI movement is twofold: firstly, it aims at changing the institutions of the asset management sector by restoring social responsibility in finance. Institutions are the collective rules and beliefs which organize a field (Friedland and Alford, 1991). Secondly, it seeks to propose alternative institutions based on SRI logics.

Despite the global spread of the SRI movement, research has indicated that the SRI movement has differed extensively both in practice and in principle in different countries (Louche and Lydenberg, 2006; Bengtsson, 2008; Sakuma and Louche, 2008; Sandberg et al., 2009). Contrary to financial markets, the SRI movement seems to exist not as a global phenomenon but as a sum of separate national movements. According to this analysis, the potential impacts of the SRI movement on the asset management sector should be examined 
through a national lens. In this article, the French SRI movement is analyzed. Two reasons motivate this choice. Firstly, the French SRI movement explicitly aims at changing the institutions of the asset management sector (Europlace, 2008). Secondly, France appears to be one of the most dynamic SRI movements in Europe. Overall, the total SRI French market has grown 615\% between 2005 and 2007, which is one of the fastest growth rates on the continent (Eurosif, 2008). Hence, a finely-detailed study of this movement should yield a better understanding of the potential role of the new social movements in reforming economic institutions.

Originally, social movement theorists portrayed social movements as 'spontaneous, unorganized and unstructured phenomena' (Morris, 1994). They now focus their attention on how political struggles shape emerging industries (McAdam and Scott, 2005). The concept of 'organizational field' (DiMaggio and Powell, 1983), which originates from institutional theory, offers a relevant unit of analysis to study this phenomenon. Firstly, it designates particular economic institutions as constituents of the wider economic system. Secondly, it embodies the common institutional logics of the field (Friedland and Alford, 199I; Thornton and Ocasio, 1999; Friedland, 2009). Institutional logics are defined as a 'set of material practices and symbolic constructions - which constitutes its organizing principles and which is available to organizations and individuals to elaborate' (Friedland and Alford, 1991). Consequently, an appraisal of how a social movement impacts the institutional logics of a field should indicate how social movements can contribute to reforming economic institutions. For this purpose, this article uses the concept of 'field framing' (Lounsbury et al., 2003). This concept encompasses both the notion of organizational field and the processes of framing which refer to the construction of meaning by a social movement (Benford and Snow, 2000). In other words, the concept of field framing refers to the interactive processes which enable the actors of both the social movement and the field - challengers and incumbents - to create, maintain and change the institutional logics of a field. In particular, this article explores the impacts of the 'field framing' of the French SRI movement on the institutional logics of the French asset management field.

Empirical findings are drawn from a longitudinal case study (1997-2009) of the French SRI movement, based on interviews, participative observation and documentary evidence. The main thrust of this study concerns the last few years of the movement. Indeed, by gaining legitimacy 
and penetrating the mainstream asset management sector, the French SRI movement seems now to be at a crossroads: its survival appears to be threatened by its success.

This article makes three main theoretical contributions to Social Movements, Institutional Change and SRI, respectively. Firstly, it demonstrates that social movements can impact economic institutions and analyzes the relationships between their success and death. Secondly, it suggests that social movements can trigger change among the institutional logics of a field and that the stabilization of a social movement around institutional logics can spawn the creation of a new field. Thirdly, it argues that SRI 'compromise-movements' can participate in restoring social responsibility to financial institutions. It also claims that social movement theory could facilitate the understanding of the dilemma of CSR movements: being successful and dying or staying alive but remaining marginal. Furthermore, it envisions that the national anchorage of SRI movements has prevented them from adopting a major role in global financial institutions. Lastly, it provides practitioners with theoretical keys to understand the pros and the cons of 'SRI labels'.

The remainder of the article is structured as follows. Section 2 explores the theoretical issues under scrutiny. Section 3 and 4 detail the research setting and methodology. Section 5 exposes the results of the case study. Section 6 discusses the findings and points to further research.

\section{Changing Institutions: The Role of Social Movements}

\section{How do social movements change institutions?}

A 'coordinated collective action form' (Touraine, 1969; Zald and Berger, 1978) can be identified

as a new social movement if it satisfies four features: having a collective identity, sharing individual resources in the pursuit of a common purpose, aiming to change existing institutions, and providing a new orientation for society. In a given organizational field (DiMaggio and Powell, 1983), institutions provide guidance on how actors should behave in the field (Friedland and Alford, 1991). The concept of organizational field has been widely developed by institutional theorists. DiMaggio and Powell (1983) defined it as organizations that, in the aggregate, constitute a recognized area of institutional life: key suppliers, resource and product 
consumers, regulatory agencies, and other organizations that produce similar services or products.

Social movements aim at transforming existing institutions. They have been traditionally designed to change institutions by opposing them from the outside. To do so, they first deinstitutionalize the existing beliefs, norms, and values embedded in the current form. Then, they create new forms which instantiate new beliefs, norms and values (Rao et al., 2000). Hence, social movements have been theorized as 'protest movements' which rally challengers against existing institutions by adopting an 'outsider' position. This relates to the traditional view of institutions as a punctuated equilibrium disturbed by exogenous jolts. The Civil Rights Movements (Andrews, 200I) and the Suffragette Movement (McCammon et al., 200I) are examples.

More recently, social movement theorists have acknowledged that social movements can also emerge among the organizational field (Fligstein, 1996, 200I). For example, Rao et al. (2003) explored how social movements underlined re-institutionalization in certain professions. They demonstrated how the Nouvelle Cuisine movement (re)shaped the institutional logics and role identities of French cuisine. In this case, social movements gather 'insider challengers' who rely on existing institutions and hitherto aim to theorize, articulate and combine new projects or practices with prevalent arrangements. Contrary to traditional social movements, these movements aim to change existing institutions not by opposing them from the outside but by transforming them from the inside. This internal change can rely on a compromise approach or a conflicting approach between incumbents and challengers. Lastly, a social movement can gather both outsider and insider challengers. Notably, this is the case for the French SRI Movement which, while emerging within the asset management field, has implicated challengers from outside organizations, such as NGOs and trade unions.

\section{The key success factors of a social movement}

The impact of a social movement on institutions often hinges on how it forms new organizations and shapes collective identities. McAdam et al. (1996) identified three key factors mobilized by challengers to succeed, usually known as a resource mobilization perspective:

I. The mobilizing structures which refer to the organizational forms (formal and informal) available to the challengers.

2. The political opportunity structures (and associated constraints) which provides the context to challengers. 
3. The framing processes defined as the collective processes of interpretation, attribution and social construction which mediate opportunity and action.

According to social movement theorists, challengers must frame the issues they defend in order to make them resonate with the ideologies, identities and cultural meanings of potential supporters of the movement, namely among the incumbents (Benford and Snow, 2000). The concept of frame refers to the work of Goffman who defines it as an 'interpretative scheme' which helps actors reduce socio-cultural complexity in order to perceive, interpret and act in a socially efficient way (Goffman, 1974). The framing of a social movement relates to its strategic creation and manipulation of shared meanings, world interpretations and problems. Therefore, framing is a cognitive mechanism which affects how people perceive the interests, identities and possibilities for social change (Campbell, 1988). It relies on the mobilizing and political opportunity structures available to the challengers.

\section{Explaining Institutional Change in an Organizational Field}

\section{The concept of 'field framing'}

The 'institutional logics' of a field refer to the 'organizational principles' of the field (Friedland and Alford, 1991) - which provide guidance on how actors in the field should behave. They provide the schemes of meaning through which actors make sense in practice of institutions. The 'field framing' of a social movement relates to the framing used by challengers to transform the institutional logics of a field. The concept of field framing is close to the concept of institutional logics. Both refer to ideas and belief systems and acknowledge the role they play in imparting direction, motivation, sense and coherence (McAdam and Scott, 2005). However, field framing differs from institutional logics on two major points:

- Firstly, it focuses on the challenging ideas and not on the dominant logics.

- Secondly, field framing concerns the political and active construction of new institutional logics by a social movement; it is not interested in the institutional logics themselves.

In other words, institutional logics emphasize the 'structures' - the outcomes of the social movement, while field framing highlights the 'structural holes' - the processes of the social movement (McAdam and Scott, 2005). 


\section{The side effect of the success of a social movement}

Little research has explicitly studied the relationship between the death and the success of a social movement (Lounsbury et al., 2003). According to previous studies (Rao et al., 2000; Lounsbury et al., 2003; Rao et al., 2003), two outcomes linked to the success of a social movement can be identified: firstly, changes in the existing institutional logics and consequently in the field; secondly, the creation of alternative institutional logics which add to the previous ones. The second outcome can lead to the emergence of a new field (Fligstein, 1996, 200I). These outcomes and their impacts on the social movement depend on the goals of the movement.

On the one hand, it appears that the primary goal of a social movement is to alter existing institutional logics. Therefore, it can be expected that once the movement has succeeded in transforming the dominant logics, it will disappear. For instance, this was the case of the Suffragette Movement. When women were given the right to vote, the movement ended. In other words, the success of the social movement leads to its death. The social movement is seen as a temporary trigger for change in a given organizational field.

On the other hand, previous research (Lounsbury, 2005) has demonstrated that a social movement can also lead - intentionally or not - to the creation of a new field, based on 'alternative institutional logics'. In particular, the new CSR social movements appear to be torn between two objectives: 'changing the existing field' and 'creating a new field'. For instance, French SRI challengers have aimed to both I) transform the institutional logics of the French asset management field (i.e. expanding SRI into conventional funds) and 2) set up a new organizational field based on SRI logics (i.e. creating an SRI market based on SRI funds). However, when a social movement aims to create a new field in addition to transforming the dominant institutional logics, the two purposes inevitably collide. Indeed, by downplaying the differences between challengers and incumbents, the success of the first goal, 'changing the existing field', jeopardizes the success of the second, 'creating a new field'. Furthermore, when a social movement stabilizes around common institutional logics, it may cease to be a movement and become a steady organizational field, instead. This dichotomy between transforming an existing field and creating a new field raises several questions: how can a social movement achieve both goals? Can an organizational field play the same role as a social movement? In other words, can a social movement stabilize around steady institutional logics? Notably, this 
would suggest that a social movement could be permanent. Lastly, are there better strategies (i.e. outsiders vs. insiders and conflict vs. compromise) according to each goal? These are questions that the following case study will attempt to answer.

In the next two sections, the article examines how the French SRI social movement has mobilized field framing in order to achieve its two goals - changing the institutional logics of the asset management field and building a new field based on SRI institutional logics. The discussion focuses on the various findings.

\section{Research Setting}

\section{What is Socially Responsible Investment?}

SRI means including non-financial criteria for integrating environmental, social, governmental (ESG) concerns into investment processes. ESG criteria relate to the non-financial criteria taken into account in SRI funds when investing. These are also known as SRI criteria. SRI dates from the American Methodist and Quaker movements that appeared during the 1920s. These investors originally refused to invest in companies present in the 'sin-industries' (e.g. alcohol, tobacco, weapons, pornography and gambling). In Europe, the first SRI funds appeared during the 1970s as a reaction against apartheid in South Africa.

Despite this long historical background, the French SRI social movement only developed in France a decade ago. Prior to this, a number of ethical funds did exist, but there was no collective movement: certain marginal investors - mainly religious - excluded a few companies for ethical reasons. They did not have a collective identity or a common purpose. The French SRI movement was formed at the end of the 1990s when a few asset managers deliberately decided to bring social responsibility to the asset management sector. To do so, challengers developed a 'best-in-class' approach to SRI, which consisted of selecting the most socially responsible companies, whatever their sector of activity.

\section{Features of the French SRI social movement}

With the exception of Canada (Gendron and Turcotte, 2007), most studies of SRI have not used new social movement theory to explore the collective action which has underpinned the development of SRI. In France, previous research has argued that SRI was led by marginal 
institutional entrepreneurs, mainly from asset management companies and social rating agencies. According to these studies (Déjean et al., 2004; Déjean, 2005; Boxembaum and Gond, 2006), the development of SRI in France appeared to be an emerging phenomenon which did not follow a collective action. In contrast, this article argues that SRI has developed in France as a result of a deliberative and organized social movement which aimed at changing the institutional logics of the asset management field. In other words, it suggests that the SRI actors described as individual institutional entrepreneurs in previous research belong, in fact, to the same social movement. The detailed description of the field framing used by the movement since the 1990s provides strong support for this assumption (cf. section 5).

Several elements can explain the differences between both approaches. Firstly, previous research on SRI in France studied the movement before it penetrated the mainstream asset management sector. So, it was difficult to identify how challengers began succeeding in changing the dominant institutional logics. Secondly, none of these studies benefited from participative observation within the French asset management sector. Yet, this in-depth integration provided a different access to the underlying organization of SRI challengers from interviews. Lastly, the approach to SRI itself differed. Whereas previous studies have analyzed SRI as a prolongation of the 1920s ethical funds, this article focuses on SRI only when it shifted from an ethical to a social movement approach. In other words, it examines SRI at the point where asset management companies decided to diffuse this type of investment within the mainstream asset management sector (i.e. since the 1990s).

Despite these differences, previous research and the findings of this case study indicate that the French SRI movement satisfies the four features of the new social movements (Touraine, 1969; Zald and Berger, 1978):

- Having a collective identity: SRI challengers feel that they belong to the same movement - friendship plays a key role. For instance, Penalva-Icher (2007) demonstrated that French SRI challengers stood together in the same community and that this solidarity was adopted for the common good: the success of the social movement.

- Sharing individual resources in the pursuit of a common purpose: for the movement to succeed, SRI challengers cooperate and share knowledge and financial resources, namely through mobilizing structures (Déjean, 2005; Penalva-Icher, 2007). Thus, SRI analysts who belong to competing asset management companies exchange ideas and share knowledge to collectively improve SRI criteria. 
- Desiring to change existing institutions: SRI challengers aim at bringing social responsibility into the institutional logics of the French asset management sector (Europlace, 2008). For instance, SRI analysts aim at cooperating with social rating agencies, brokers, trade unions and NGOs to convince mainstream (i.e. conventional) asset managers inside their company of the financial interest of SRI.

- Providing a new general orientation for society: this last feature has been developed especially for the new social movements. According to the challengers, the integration of SRI criteria should introduce social responsibility to the financial markets (Europlace, 2008). Namely, during the recent financial crisis, SRI challengers explained in the media that SRI may be one answer to the current economic problems (Zouati, 2009).

The French SRI movement gathers both 'insider' challengers from the asset management sector (e.g. asset management companies, social rating agencies, brokers, and so on) and 'outsiders', such as NGOs and trade unions. Outsiders are actors who do not usually belong to the asset management sector. Both types of challengers have participated in the framing of the movement, including outsiders who are indirectly linked to the asset management sector and who favor the notion of the asset management field over the asset management sector. The asset management field is then wider than the asset management sector. The institutional logics of incumbents (i.e. mainstream actors) consist of favoring financial performance over other criteria, including SRI criteria. The new institutional logics developed by challengers aim at adding SRI performance to financial performance. This is obtained through the integration of SRI criteria into investment processes. The goal of challengers is twofold: I) to transform the dominant institutional logics by encouraging conventional actors to integrate SRI criteria when investing; 2) to create a new field based on SRI logics by developing SRI funds that are different from conventional funds.

\section{Research Methods : Data Collection and Sources}

\section{Interviewees and interviews}

Key interviewees were identified after a one-year period of participative observation within the French SRI movement (June 2006-June 2007), conducted as an SRI analyst in a French asset management company specialized in SRI. Aiming at exploring the phenomenon of the penetration of SRI into the mainstream asset management sector, two sets of people were interviewed. The first set of interviewees grouped as SRI challengers. They included SRI asset 
managers, SRI trade associations, trade unions, social rating agencies, SRI consultants and SRIoriented NGOs. The second group of interviewees comprised incumbents: actors known as mainstream actors who showed a growing interest in SRI. They included asset managers, the asset management trade association, financial institutions, brokers, finance-oriented NGO, pension funds and consultants. In this fashion, 33 interviews were conducted during the period from July 2007 to March 2009. Fifteen interviews were conducted within the challengers group and 18 within the incumbents', in all, five asset management companies, four financial institutions, two brokers, two trade unions, three consultants, one trade association, two NGOs, one pension fund, one think-tank and five social rating agencies. During the interview period, the two groups gradually intertwined.

Semi-structured interviews lasting between 45 minutes to two hours and 15 minutes were conducted face to face for 29 interviews. Telephone interviews from one to two hours with four other informants were based on a questionnaire previously sent to the interviewee. Twenty-eight interviews were tape-recorded and transcribed word-for-word. For the five other interviews, interviewees' comments were recorded in handwritten notes, which were reviewed, edited and transcribed immediately. Further details are provided in Appendix I.

All interviewees were asked to (I) explain how they perceived SRI personally, (2) describe to what extent and how their activities had been impacted by SRI over the past decade, (3) tell how they analyzed the relationships between SRI and the mainstream asset management sector, (4) envisage the future of SRI in France. Other questions were tailored to the interviewees' specific roles.

\section{Participative Observation}

According to the typology of membership roles designed by Adler and Adler (1987), the researcher adopted the position of an active member. That is, the researcher 'assumed a functional role in addition to the observational role; which facilitated trust and acceptance of the researcher, but increased the identification of the researcher with members of the setting' (Adler and Adler, 1987). This participative observation within the SRI movement as an SRI analyst continued without interruption from June 2006 to June 2009 and was supported by data gathering based on day-to-day field notes. The researcher participated in think-tanks, working groups, SRI road shows, conferences and business meeting with consultants, agencies and 
brokers, representing almost 40 formal events per year. These formal meetings were completed by various informal discussions with various field actors and a continuous strategic surveillance thanks to the amount of information garnered from the field's actors - specialized newsletters and media coverage. This ongoing participative observation allowed for supplementary information to be gathered throughout the interviews with a comprehensive, tangible knowledge of SRI during the movement's turning point.

\section{Documents and Secondary Data}

Extensive data were collected from documentary sources, including trade association surveys, professional reports (consultants, asset managers, brokers and social rating agencies), NGO studies, newspapers, newsletters, websites, theses, academic papers and books. Market data amount of assets and number of funds, asset managers and SRI analysts - and press coverage were based on information on company websites, Novethic, Factiva and the AMF (Autorité des Marchés Financiers) ${ }^{2}$.

\section{Data Analysis}

To analyze the data, a field analytic method was used (Scott et al., 2000; Lounsbury et al., 2003), which consists of tracking changes over time in a field. Notably, this method focuses on the critical events, such as organizational births, deaths, mergers and various types of transformation, for example, changes in clients' demands and press coverage. This method has been judged particularly relevant for supporting the investigation of long-term change processes (Goodrick, 2002). For this purpose, an approach was used which resembled the sequence of sense-making strategies (Langley, 1999) that would later be called grounding, organizing and replicating (Chiles et al., 2004).

Grounding strategies refer to theories that are derived from data, systematically gathered and analyzed through the research process. A key process in grounded theory is the coding of the data. An 'emerging coding' system was adopted which means that codes emerged from collected data into three successive levels of coding (Strauss and Corbin, 1998). The first level refers to open and axial coding and consists of coding and then organizing every incident into categories: core variables which referred to broad conceptions. For instance, the code 
'Mainstreaming' was used when actors evoked the integration of SRI criteria into financial analysis and the code 'Ethics' when actors speak about the ethical approach of SRI. After having found the core variables, data was coded with a selective coding (second level). Hence, the code 'Mainstreaming' was divided into two sub-codes: 'Financial Valuation' when the mainstreaming approach followed a financial approach and 'Social Responsibility' when the integration of SRI criteria into the mainstream was triggered by responsibility concerns, such as external pressure. In the same way, the code 'Ethics' was divided into two sub-codes: 'Exclusion' when companies were excluded according to their sector and 'Best-in-Class' when the best socially responsible companies were selected in each activity sector, whatever their sector. At the same time, new data were sampled with the core in mind. As categories, subcategories, and relationships emerged, this data-driven conceptual framework was compared with a broad spectrum of academic literature in social sciences. At this point, a theoretical coding system (third level) was mobilized, based on social movement theory and the concept of field framing. This aimed at conceptualizing how the substantive codes relate to each other as hypothesis to be integrated into a theory. For instance, using the code 'Mobilizing Structures' was used when identifying organizational forms used by challengers to convince the incumbents. This first stage of analysis therefore yielded a set of concepts grounded both in theory and in data.

Organizing strategies draw process data in a systematic fashion (Langley, 1999). For this purpose, a chronological display (cf. figure I) is constructed to chart the temporal sequence of salient events of the French SRI movement from 1997 to 2009. The event categories and specific events were derived from my grounded theory analysis. This qualitative analysis was complimented by quantitative data (cf. figures 2 to 4), which tracked changes in the number of asset management companies proposing SRI funds (1999-2008), the amounts of assets and number of funds in SRI compared to the total market (2000-2008), the number of articles mentioning SRI in French newspapers and the number of SRI analysts in asset management companies (2000-2008).

Replicating strategies are techniques for 'decomposing the data for the replication of theoretical propositions by phase, by event, and by case' (Langley, 1999). For this purpose, temporal bracketing was used which allows the tracing of the theorizing process over time. As shown in figure I, the French SRI movement is structured into the following periods: 
I. The Pioneering Era (1997-1999) which refers to the framing of a collective identity by challengers.

2. The Building Era (2000-2003) which relates to the framing of the challengers' logics on the incumbents' ones.

3. The Legitimating Era (2004-2005) which coincides with the penetration of challengers into the incumbents' field.

4. The Mainstreaming Era (2006 to the present) which fits the adoption of the challengers' logics by incumbents.

Although the field analytic method is widely used in field studies (Scott et al., 2000; Lounsbury et al., 2003), it suffers from several limitations. Firstly, it has been difficult to trace in detail the full history of the field due to the lack of data. For instance, all the actors who participate in the field could not be interviewed. Moreover, the analysis had to focus on certain key events, at the expense of other aspects of the field framing. Secondly, this method meant relying on secondary data to analyze the first years of the movement. In particular, previous research and interviews were used to trace events that took place prior to 2006. This prevented experiencing in practice certain assumptions made by other researchers and interviewees (even if most of interviewees belonged to the field since the beginning of the movement). Lastly, even if in the field for a long period of time, it has been impossible to fully access the 'true' motivations of actors through interviews. However, the wide-ranging array of interviews, observations, documents and secondary data provided rich contextual details, enables triangulation between the different sources of information and to accurately account for the different stages of the movement since its beginning. In the next section, an historical account is provided with evidence highlighting the importance of field framing to the efforts of the French SRI social movement to alter established institutional logics and propose new ones within the asset management field.

Figure I through 5 [Insert FIGURES I to 5 here]

\section{Emergence, Development and Future of the French SRI Movement}

\section{7-1999: The Pioneering Era}

The creation of the first French social rating agency, Arese, in June 1997, set the wheels of SRI in motion. From the start, Arese cooperated with a few asset managers. This cooperation was 
strategic for both sides: I) without clients, Arese could not survive; 2) without a social rating agency, asset managers could not create SRI funds. This cooperation was also social. Both actors aspired to the same goal: bringing social responsibility into the asset management field. Through informal networks, challengers exchanged their experiences and their dreams. In this way, challengers incrementally built the collective activity of their movement.

In order to succeed, the SRI social movement wanted to be accepted by the rest of the asset management field. Indeed, being field members, challengers needed to frame their movement on dominant institutional logics to gain legitimacy. Moreover, strongly criticizing their peers would have meant questioning what they had done for years and what they continued to do. This construction of legitimacy took the form of the conception of products that conformed to the institutional logics of the asset management field (Déjean, 2005). Firstly, social rating was built on the financial analysis model:

"When we founded Arese ten years ago, our system was merely qualitative. We later designed a system of quantitative scoring that was more convincing for our clients."

Arese, Former Analyst, 2007

Secondly, the official goals of SRI funds were clearly not ethical. By taking into account SRI criteria, SRI asset managers pleaded in support of higher financial returns in the long term. However, this assertion remained a belief; the adoption of SRI relied first on personal convictions. This necessary acceptance by the asset management field also obeyed technical constraints. To be legal, SRI funds had to receive clearance from the AMF. In other words, SRI funds were technically akin to conventional funds (e.g. same practices in terms of risk, diversification and investment processes).

Since challengers belonged to the same social movement, they preferred cooperation to competition (Penalva-Icher, 2007). This sharing of individual resources also contributed to bringing help to people without the support of surrounding networks due to their insurgent position. Indeed, in 1999, only 16 companies offered an SRI fund and the total amount of SRI assets in France was less than to $€ 0.8$ billion. 


\section{0-2003: The Building Era}

Action undertaken by the French government was a significant inducement to growth. Firstly, the government enforced two laws: the NRE Law (200I) which obliged listed companies to report on the social and environmental aspects of their activities and the Fabius Law (200I) which both permitted and affirmed the importance of employee saving funds. Secondly, in 2000, the government created a public pension fund with a dedicated SRI policy: the FRR (Fonds de Réserve des Retraites) $)^{3}$. This major cue from one of the France's major potential investors clearly explained to a large extent the entry of mainstream actors on the SRI market. This rise in demand was confirmed by the creation in 2001 of the CIES (Comité Intersyndical de l'Épargne Salariale) $)^{4}$ which provided a trade union 'SRI label' to a range of SRI employee saving funds.

Drawing on these political opportunities, challengers began to build mobilizing structures to support their movement. They aimed at framing their logics on the logics of incumbents (i.e. financial logics). In 2000, the ORSE (Observatoire sur la Responsabilité Sociétale des Entreprises) ${ }^{5}$ was founded by approximately fifteen members - most of whom were asset management companies. The ORSE rapidly grouped 100 actors, principally among financial institutions and listed companies. This association aspired to give endorsement to the idea that CSR yielded performance. Firstly, the ORSE helped listed companies to adopt CSR institutional norms. Then, it contributed to collectively standardizing SRI criteria and SRI practices, thereby boosting the development of SRI. In other words, through its mobilizing structures, the SRI social movement endeavored to build a relationship between SRI and financial performance, enabling its selffulfilling prophesy (Gond, 2006):

"The SRI market [...] effectively auto created. The market created itself."
Broker, Head of SRI research, 2007

Meanwhile, two other mobilizing structures were launched: I) the FIR (Forum pour I'Investissement Responsable) ${ }^{6}$ which aimed at promoting the concept of SRI and its practices; 2) the SFAF (Sociéte Française des Analystes Financiers). Through these structures, challengers aimed at I) agreeing on the field framing of the movement (the ORSE and the FIR);2) convincing the asset management field of the relevance of SRI, namely by influencing financial analysts (SFAF). In 200 I, the professionalization of the SRI movement was helped by the creation of Novethic; an 
independent organization financed by the Caisse des Dépôts et Consignations, a public financial institution. Novethic wanted to build the legitimacy of the SRI movement by providing quantitative public data (Giamporcaro-Saunière, 2006). By offering definitions and assessments of SRI funds, Novethic gradually revealed the existence of the SRI movement to the media and to the asset management field.

In 2002, Arese became Vigeo and the former CEO of Arese formed CoreRatings. These two agencies dominated the French SRI market for over two and a half years. Consequently, SRI funds were managed according to the same social ratings. This technical mimesis also helped produce common practices. Moreover, these agencies created SRI indexes (e.g. Aspi Eurozone, Ethibel Index, DJSI Stoxx and FTSEE4Good) which became reference points for SRI asset managers (Déjean, 2005) and contributed to bringing SRI into the heart of stock markets. Vigeo had a structural and key impact on the SRI movement. Firstly, by fitting the French business model, based on 'partnerships' with financial institutions, trade unions and listed companies, the agency enabled the recognition of SRI by the French elites (Zarlowski, 2007). Secondly, it helped carve out the positive relationship between SRI and financial performance by conceiving SRI analysis which aimed at identifying the SRI criteria which would impact financial performance:

"You're not here to save the planet, as they say. You work for investors. So you really do need a vision of the economic impacts on firms and how they can impact their business."

Vigeo, Former Analyst, 2008

To obtain the CIES label, asset management companies had to devote internal resources to SRI. The first SRI Analysis Department was created in 2002. Asset management companies coined a new term: the buy-side SRI analyst. At the end of 2003, SRI as a niche had been developed but remained an emerging inexperienced activity. As stated in the Eurosifs annual report (2003) on the French SRI: 'For the moment, however, most traditional financial institutions are waiting to see how the market unfolds, while other non-financial players decide how to go forward.' The social movement began to be recognized but had not yet succeeded; incumbents vacillated. In 2003, the Carbon Disclosure Project (CDP) was launched to 
encourage 'private and public sector organizations to measure manage and reduce emissions and climate change impacts. ${ }^{8}$ Mainstream investors began to feel the pressure.

\section{4-2005: The Legitimating Era}

The SRI market grew and appeared to be shifting structurally from an offer market to an institutional demand market. In 2004, the ERAFP (Établissement de la Retraite Additionnelle de la Fonction Publique $)^{9}$, the second largest French public pension fund, was created. As did the FRR, the ERAFP clearly showed its willingness to invest in SRI: '[...] it has been decided to adopt socially responsible investments for the totality of ERAFP's assets. ${ }^{\prime 1}$ Enthusiasm for SRI also existed among private pension funds as illustrated by the decision of AGIRC (Association Générale des Institutions de Retraite Complémentaire des Cadres)-ARCCO (Association pour le Régime de Retraite Complémentaire des Salariés)" to invest $€ I 00$ million in SRI funds in 2005. These institutional clients were partly responsible for shifting SRI to financial logics. Firstly, they rejected the idea of SRI indexes contributing to their failure among invitations to tender: asset managers had to beat the conventional market. Secondly, they favored a 'best-in-class' approach, which occasionally maintained high financial returns at the expense of SRI. As a result, these financial features casted doubt on the sincerity of the SRI movement and clients became mistrustful:

"When individual clients buy an SRI product, they face a dilemma. [...] Clients are satisfied when the product achieves a good financial performance, but then, when they look closer at the first ten lines of the portfolio, they say: "You've got TOTAL, but that's just not right!" 12

Asset Management Industry, Head of SRI, 2007

To keep the movement alive, the SRI movement had to highlight its distinguishing features. In 2004, to regulate the movement and signal that SRI was of paramount importance for the asset management field, the AFG (Association Française de Gestion financière) ${ }^{13}$ created an SRI Commission. In the same vein, both challengers and incumbents (Eurosif, FIR and AFG) decided to launch a 'Transparency Code for Public SRI Funds' in 2005. This encouraged asset managers to describe their investment processes. However, the penetration of mainstream 
actors into the SRI movement also raised problems; the latter would have acted out of self interest:

"We realized that those who believed in SRI were those who dedicated internal resources. Otherwise, it was what we called "anisette" offers", meaning I/7 SRI and 6/7 everything financial!"

Trade Union, CIES Member, 2007

The penetration of the mainstream asset management field by the SRI movement was helped in 2005 by the launch of two international SRI initiatives dedicated to mainstream investors: firstly, the EAI (Enhanced Analytics Initiative) which addressed the absence of quality, long-term research studying material, non-financial issues; secondly, the PRI (Principles for Responsible Investment), which claimed that 'environmental, social, and corporate governance (ESG) issues can affect the performance of investment portfolios. ${ }^{15}$ The PRI had a strong impact on the success of the movement since the principles demonstrated to mainstream investors that SRI existed. As a result, by questioning existing practices, SRI provided financial actors with the cultural resources necessary for critical and reflexive action:

"Asset managers began to sign the PRI for their SRI funds, and surprisingly, this encouraged them to progressively integrate SRI criteria into the rest of their investments as well."

Social Rating Agency, Head of SRI Research, 2007

Making the most of this attention, SRI challengers decided to directly penetrate mainstream organizations. Coming from social rating agencies, challengers aspired to prove the positive relationship between SRI and financial performance: something that had not yet been proven to date. To do this, they opened mainstream-oriented SRI Departments within the majority of brokers in 2004 and 2005: CM CIC Securities, Société Générale Corporate and Investment Banking, Oddo Securities and Cheurreux, for example. Financial analysts began to be increasingly attuned to SRI: 
"I can tell you that we have people here who work on these SRI criteria when it comes to acquisitions, mergers, or trading..."

Broker, Head of SRI Research, 2007

At the end of 2005, SRI was no longer a small movement led by activists, since the social movement had been recognized by mainstream actors. SRI was about to take up its first challenge: transforming the asset management field. However, the asset management field had not changed in essence and SRI still represented less than one per cent of total assets. SRI was a legitimate but still emerging practice.

\section{6-2009: The Mainstreaming Era}

While SRI adopted financial logics, mainstream actors took over SRI logics. These two movements gradually resulted in a merging of both logics. In 2006, the term 'SRI Integration' was used as a concrete theory for the first time in Novethic's annual study of the market (2006):

"We have taken into account a new demand which seems to be sustainably accepted amongst investors: the transversal integration - case by case - of non-financial analysis criteria into classical financial analysis."

At the end of 2007, the SRI market, as such, measured a third of the size of the 'SRI Integration' market in terms of assets. In regard to this integration, the FRR decided in 2008 to adopt SRI screening for all its investments. Even Paris Europlace - the organization which promoted Paris as a financial market place - affirmed the importance of SRI in a report (Europlace, 2008): it was henceforth a matter of business for the sector. Gradually, SRI and financial analyses became faces of the same (financial) coin:

"I think that we're experiencing a phenomenon of integration. Depending on the management, depending on the funds, integration will be more or less important."

Asset Management Company, Head of SRI, 2007 
In 2007, SRI Research became a category within the Financial Analysis prizes awarded to the profession. Along the same lines, Cheuvreux was the first broker to sign the PRI in 2008. The asset management sector officially recognized that non-financial analysis belonged to financial analysis. The publication in 2007 of a special SRI issue by the Journal of the SFAF confirmed this adoption. Notably, this evolution was illustrated in 2007 by the creation of the Swiss ASSET4, a new type of social rating agency which - contrary to previous social rating agencies - primarily targeted mainstream investors rather than SRI investors. ASSET4 defined itself as the Bloomberg of 'non-financial' corporate metrics. To create more value, SRI and financial analysis needed to be merged. This adoption of SRI criteria by mainstream investors contributed to converting the previous existing social rating agencies into database providers. Increasingly, social rating agencies began modeling themselves on financial agencies:

"Personally, l'm under the impression that agencies are tending to become like ASSET4. [...] I think that they will evolve in the same way as financial agencies."

Asset Management Company, SRI Analyst, 2008

This integration did not mean that SRI was no longer concerned with social questions. On the contrary, it illustrated that financial actors began recognizing the need to take into account SRI criteria when investing. The success of SRI was explained to a certain extent by the fact that SRI did not sidestep important issues. SRI embodied the undergoing change of economic institutions. Global society faced new challenges: climate change, pollution, hydraulic stress, poverty, and so on. The financial crisis argued in this sense: financially-driven, short-term investments revealed themselves to be dangerous, included for financial performance, only.

"Financial actors begin to admit that there are limits to the economic business model they've been promoting for years. [...] The shortcomings of the market have shown the necessity of having better non-financial analysis."

Asset Management Company, Head of SRI, 2007

Nevertheless, the mainstreaming of SRI had a side-effect. As SRI criteria became a means to achieve better financial performance, SRI criteria shifted away from their first goal: restoring 
social responsibility in financial markets. Certain challengers feared that this move to the mainstream would obliterate the original purpose of the movement:

"I'm a little afraid by the fact that we will separate SRI issues because they're difficult to demonstrate in terms of business. But these are the reasons why I wanted to work in SRI."

Asset Management Company, SRI Analyst, 2008

Lastly, a number of historic challengers suffered from this mainstreaming. Since they were competitors, cooperation between challengers and incumbents led to conflicts. As mainstream actors had taken up the slack, small asset management companies and social rating agencies were in a peculiar predicament. They did not have the means to face competition in a market where size brought credibility. If they were the erstwhile leaders, they were henceforth the losers of SRI integration.

\section{The Future: A Coexistence of Two Types of SRI?}

Two trends seem to be emerging at present: I) the continuation of the merger between SRI and mainstream logics; 2) the emergence of a new, more committed SRI movement. When former challengers transform into incumbents, a new SRI social movement appears.

\section{'Mainstream SRI': transforming the Asset Management field}

The term 'Mainstream SRl' is increasingly used by financial actors to designate the traditional 'best-in-class' SRI funds which attempt to maximize both SRI and financial performance. Firstly, the appearance of the 'mainstream' term within the movement confirms that SRI has squared with common institutional logics. Secondly, it denotes a move to mainstream asset management. The demand for SRI integration keeps rising. No less than $20 \%$ of the mainstream market is expected to become SRI in ten years (Robecco and Booz, 2008). With this in the offing, Mainstream SRI seems to be full of promise for the asset management field. This trend is confirmed by the diversification of SRI towards different financial products (e.g. funds of funds or hedge funds) and SRI thematic funds (e.g. renewable energies, green technologies, water, and so on). 
A growing number of conventional funds are now integrating SRI criteria to achieve better financial performance by anticipating those costs linked to a below-average performance in social, environmental and governmental domains. At the end of $2009,90 \%$ of conventional funds in France were estimated to integrate at least one SRI criterion, compared to $61 \%$ at the end of 2008 and 3\% at the end of 2007 (Novethic, 2010). The idea is less about upgrading socially responsible firms than investing in financially promising industries and SRI criteria are increasingly selected according to their impact on business. However, this integration is diverse among asset management companies and it remains difficult to know what SRI integration means in practice. Consequently, certain observers doubt the impact of the SRI integration on investment practices (Novethic, 2010).

If mainstream funds mobilize SRI criteria and SRI funds increasingly favor a business approach, how can we differentiate between the two? Indeed, as SRI penetrates the mainstream, the differences between challengers and incumbents gradually fade. This threatens the survival of the SRI movement. To stay alive, SRI actors have recently created an 'SRI label' to separate their institutional logics from financial ones. In September 2009, Novethic launched the first French SRI label for SRI public mutual funds: 92 funds among the 250 funds listed by the organization have obtained the label so far. The purpose of this label is to provide SRI with official institutional logics. However, this stabilization over common institutional logics is likely to transform the SRI movement into a new field. As for profit-sharing funds, this recognition could trigger interest among individual investors by offering financial advantage from the state. It could also help SRI to be identified by the state as a key factor in the financial system. For instance, SRI challengers are now working with the French government on a new law which would oblige all asset management companies to account for the SRI aspects of their investments. ${ }^{16}$ However, although challengers assert that SRI could be a solution to the financial crisis, national states have not as of yet paid attention to the movement as a remedy.

\section{A 'Committed SRI': proposing a new SRI}

If pioneers do not win, they can go back to being pioneers. While a number of challengers are gradually converted into incumbents, contributing to SRI integration, others aspire to propose a new, more committed type of SRI. This means an SRI which favors SRI over financial logics. These challengers specialize in particular issues, such as human resources, shareholder activism 
or developing countries. For the first time, ethical questions seem to penetrate a movement which first avoided them to gain legitimacy:

"People were saying that these ethical questions were no longer important. [...] But l've noticed that this last year, these last two years in fact, ethical questions have begun to reemerge."

Social Rating Agency, Client Relationship Manager, 2008

By proposing a new type of SRI, these challengers also respond to a new demand among institutional investors who wish to I) trace their SRI risks; 2) shield themselves from scandals, such as child labor or pollution; 3) favor long-term, diversified investments. For a number of years, observers believed it was impossible for SRI to avoid the following dilemma: remaining small but with the risk that no investors will be interested in them, or growing and institutionalizing, but with the risk of losing their critical function (Louche, 2004). However, contrary to expectations, the achievement of SRI's first goal could give birth to its second. Now that SRI has become legitimate, the social movement moves away from financial logics and a new SRI appears. In keeping with this trend, a new category appeared in the classification of SRI funds provided by Novethic in 2009: 'ethical funds'. At the beginning of 2010, there were more than 68 funds in this category. For the first time, French asset management companies offer SRI

funds based on exclusion. Certainly, what the movement is devising now will penetrate mainstream tomorrow. However, challengers realize that to be successful, they will have to cogently advocate what they propose is relevant... SRI is not dead, SRI has just begun.

\section{Discussion and Conclusions}

\section{Summary of Findings}

PIONEERING: SRI as a social movement had two goals: I) to change the institutions of the asset management field; 2) to build a new SRI field. To be accepted by incumbents, SRI challengers framed their institutional logics on financial logics: the most socially responsible firms should be the most profitable in the long term. They remained a marginal movement, unrecognized by mainstream actors for three years. However, this initial collaboration managed to carve out the collective identity of the social movement. 
BUILDING: the advent of supportive political opportunity structures, through an institutional SRI demand by the creation of public pension funds, rendered SRI conspicuous. As a result, most mainstream actors offered SRI funds. Seizing this opportunity, SRI challengers built mobilizing structures which would help make their claim a reality. These formal organizations enabled them to agree on common logics.

LEGITIMATING: realizing the importance of SRI for the field, the profession aimed at regulating the social movement. Its first priority was to bring transparency. At the same time, challengers penetrated into mainstream organizations to infuse SRI logics among the incumbents. However, the adoption of financial logics by SRI had an unforeseen outcome: it undermined the motivations of the movement.

MAINSTREAMING: in the aftermath of the upheaval of the financial markets, challengers argued that SRI would restore a long-term view. SRI integration illustrated this trend. Both institutional logics began to merge, which threatened the survival of the social movement.

FUTURE: as a result of its success, the movement could die out. To ward off its death, the movement has just introduced an 'SRI label' which aims at differentiating challengers from incumbents. Nevertheless, a number of questions are being raised concerning the financial approach of SRI favored until now by the movement. By selecting those SRI criteria which impact business only, the original aspiration of SRI to restore social responsibility in financial markets may disappear. With this mind and to eschew this mainstream approach, other challengers are developing a new 'Committed SRI'. Therefore, by originally refusing an ethical approach, SRI challengers would have perhaps gained the authority to ultimately shift from financial logics.

\section{The role of social movements in transforming economic institutions}

Although institutional theorists have recently acknowledged that institutional logics may change through agency, namely through collective institutional entrepreneurship (Lounsbury et al., 2003), they have said little about how existing logics are dismantled and new logics are put in place. This study recasts social movements as a trigger for change within economic institutions. The gradual transformation of the institutions of the French asset management field by the French SRI movement has demonstrated this point: SRI social movements can play a prominent role in reforming financial institutions. Traditionally, such impacts have been theorized as 
external jolts; fields go through upheaval because of protest-movements. This external view is completed here by an internal focus: compromise-movements change the existing logics through the incumbents' ones. They provide them with the necessary resources to take a critical look at their own practices. This compromise approach questions the traditional perspective of social movements, usually associated with conflicts and outsiders' actions.

In the case of the French SRI movement, it appears that SRI challengers have adopted the strategy most likely to succeed. Indeed, on the one hand and contrary to other countries, the French SRI movement could not only rely on ethical investors, such as religious organizations. Consequently, change needed to be driven by insiders. On the other hand, these insider challengers belonged to the French asset management field. As a result, it was difficult for them to criticize their institutional logics (i.e. financial logics) to develop new ones (i.e. SRI logics). This would explain why they have favored a compromise approach. In other words, it appears that the French SRI movement has adapted its field framing to the features of its environment to succeed. This strategic approach is conducive to an instrumental view of social movements, which differs from a view of social movements as 'spontaneous, unorganized and unstructured phenomena' (Morris, 1994). Drawing on the case study, four strategic phases which refer to the key stages of the field framing of compromise-movements have been identified:

- PIONEeRING: framing of a collective identity by challengers.

- BUILDING: framing of the challengers' logics on the incumbents' logics.

- LeGITIMATING: challengers - and their logics - penetrate the incumbents' field.

- MAINSTREAMING: incumbents adopt the challengers' logics.

However, other studies of compromise-movements are needed to generalize these findings on a broader basis. For this purpose, the concept of field framing could provide an interesting analytical framework.

These findings argue in favor of national differences between SRI movements. For instance, SRI activists in other countries, such as Denmark, have geared towards coercing firms into being socially responsible (via the law or by an external pressure, such as the media) (Bengtsson, 2008). Although this national anchorage has been a key factor of success of the French movement (Zarlowski, 2007) by adapting the field framing to the features of the environment, it could also have stunted the role that SRI movements could have played in the 
global financial crisis. SRI social movements would need to be global or at least to cooperate internationally to be able to structurally impact global financial institutions. Notably, further research in different countries is required to explore whether and why insiders' strategies based on compromise have been favored over outsiders' strategies based on conflicts. In particular, national comparisons between SRI movements could help understand I) the national impacts on the field framing of SRI, 2) the co-evolutions and differences between the national SRI movements and 3) whether SRI movements are global movements.

\section{The economic success of SRI}

The economic success of the French SRI Movement raises questions about its motivations. Could SRI challengers have adopted the social movement strategy not to transform the institutional logics of the French asset management field, but rather to diffuse a new financial product in the field? These criticisms have been directed toward other CSR movements which have emerged within economic institutions, such as fair-trade (Gendron and Turcotte, 2007) or recycling (Lounsbury, 2005). In the case of the French SRI movement, the initial desire of SRI challengers to transform the dominant institutional logics argues in favor of a social movement. Indeed, the study clearly demonstrates that the movement did not benefit from a major business interest among the field for a number of years. SRI challengers were personally committed to SRI succeeding, even though they had no personal and business interest in doing so. Moreover, until recently, very few incumbents believed in the success of SRI. Lastly, the movement constantly gathered the four features of the new social movements (Touraine, 1969; Zald and Berger, 1978). Hence, the economic success of a social movement does not seem to contradict its aim to provide a general orientation for society. In contrast, since CSR social movements attempt to transform economic institutions, their economic success would be part of their accomplishment. The economic success of SRI has appeared to be a means for the social movement to transform the dominant institutional logics.

\section{The future of SRI}

Social movement theory has suffered from a lack of research on the relationship between the death and the success of social movements (Rao et al., 2000; Lounsbury et al., 2003; Rao et al., 2003). This article offers interesting insights into how a social movement endeavors to maintain 
momentum despite its success. It demonstrates that a social movement can be torn between two goals: I) to change the dominant institutional logics; 2) to build alternative institutional logics. Additionally, this study illustrates how the consolidation of a social movement around common institutional logics can spawn the creation of a new field. This dilemma is well recognized in CSR literature and is referred to as the 'niche vs. mainstream' debate (Louche, 2004; Vogel, 2005; Azoulay and Zeller, 2006; Crifo and Ponssard, 2009). The use of social movement theory enables us to explain why this debate occurs. It is linked to the intrinsic nature of social movements: their success threatens their survival. Here, the official recognition of the differences between challengers and incumbents via an 'SRI label' could permit the maintenance of the movement through an official agreement on SRI institutional logics. However, this stabilization could remodel the social movement in a stable field. Then, a question emerges: will this transformation into a steady organizational field mean that the movement strays from its primary raison d'être of changing dominant institutional logics?

Since the movement has begun to have some success among the mainstream, the social movement has faced new difficulties. SRI challengers have hesitated between disappearing and keeping the movement alive and complaints about the motivations of certain SRI actors have emerged. Today, the movement appears to be at a crossroads: while some actors want to stabilize the existing SRI logics around an SRI label, others would prefer to diffuse the SRI logics into the mainstream. Lastly, other challengers wish to begin a new 'Committed SRI' movement, more demanding than the previous one. By continuously increasing the demands for change, the social movement could survive. These different trends seem to demonstrate that the movement is currently losing its collective identity. Thus, if a new social movement or a new organizational field emerges, the latter is likely to be different from the original one (i.e. different challengers with a different collective identity and a different purpose). These findings argue in favour of the hypothesis according to which the success of a social movement regarding the transformation of the dominant institutional logics - leads to its death.

Four future scenarios can now be envisaged. Firstly, a new SRI organizational field could be created by agreeing on common institutional logics, notably thanks to an 'SRI label'. According to the purpose of the field members, this field could attempt to keep transforming the dominant institutional logics of the French asset management field. In such conditions, it can be imagined that the field could keep behaving as a social movement. This would prove that an 
organizational field can play the same role as a social movement. Secondly, field members could aim to no longer transform the dominant institutions logics of the French asset management field. SRI would be transformed into a new financial product and the movement would end. Thirdly, SRI logics could enter the mainstream. The institutional logics of the field would be transformed, which, in turn, would lead to the death of the social movement. Lastly, 'Committed SRl' challengers could launch a new social movement, more demanding than the previous one. After a while, it can be expected that this new social movement will face the same problem as the previous one and this, until its transformation into a steady organizational field or its death. However, further research is needed on the future of the French SRI Movement and other new social movements to argue in favour or against these different hypotheses.

Whatever the future of the movement, the mainstreaming of SRI and its associated shift from SRI to finance raises important questions about what the goal of SRI should be. Indeed, the French movement has clearly framed SRI on financial logics in order to succeed, and this, at the expense of SRI logics. At a time when SRI aims at beginning mainstream in other countries, such as Scandinavia (Bengtsson, 2008), this French experience may teach other SRI movements about the side-effects and dangers of mainstreaming. In doing so, the study could help practitioners to understand the pros and cons of SRI labels, by offering a theoretical understanding of the role of such labels to differentiate SRI from mainstream in terms of institutional logics. 


\section{References}

Adler, P. A., \& Adler, P. 1987. Membership Roles in Field Research. Newbury Park CA: Sage Publications.

Andrews, K. T. 200I. Social Movements and Policy Implementation : The Mississippi Civil Rights Movement and the War on Poverty, 1965 to 197I. American Sociological Review, 66(I): $71-95$.

Azoulay, O., \& Zeller, V. 2006. ISR : stratégie de "niche" ou "mainstream" ? [SRI: A 'Niche' or a 'Mainstream' Strategy?]. Revue d'Economie Financière, 85: 191-208.

Barker, R. S. 1990. Political Legitimacy and the State. New York: Oxford University Press.

Benford, R. D., \& Snow, D. A. 2000. Framing Processes and Social Movements: An Overview and Assessment. Annual Review of Sociology, 26: 61 I-639.

Bengtsson, E. 2008. A History of Scandinavian Socially Responsible Investing. Journal of Business Ethics, 82(4): 969-983.

Boxembaum, E., \& Gond, J.-P. 2006. Micro-strategies of Contextualization Cross-national Transfer of Socially Responsible Invesment. DRUID Working Paper, 06(24).

Campbell, J. 1988. The Power of Myth. New York: Doubleday.

Canel, E. 1997. New Social Movement Theory and Resource Mobilization Theory: The Need for Integration. In M. Kaufman, \& K. Dilla (Eds.), Community Power and Grass Roots Democracy: 189-221. London: Zed Books.

Chiles, T. H., Meyer, A. D., \& Hench, T. J. 2004. Organizational Emergence: The Origin and Transformation of Branson, Missouri's Musical Theaters. Organization Science, 15(5): 499-5I9.

Crifo, P., \& Ponssard, J.-P. 2009. La Responsabilité Sociale et Environnementale des entreprises est-elle soluble dans la maximisation du profit? [Is Social and Environmental Responsibility Soluble within Profit Maximisation?]. Sociétal, 66 - 4ème trimestre.

Davis, G. F., \& Thompson, T. A. 1994. A Social Movement Perspective on Corporate Control. Administrative Science Quartely, 39(I): I4I-173.

Déjean, F. 2005. L'Investissement Socialement Responsable - Etude du cas français [Socially Responsable Investment - A Study of the French Case]: Vuibert. 
Déjean, F., Gond, J.-P., \& Leca, B. 2004. Measuring the Unmeasured: An Institutional Entrepreneur Strategy in an Emerging Industry. Human Relations, 57(6): 74I-764.

DiMaggio, P. J., \& Powell, W. W. 1983. The Iron Cage Revisited: Institutional Isomorphism and Collective Rationality in Organizational Fields. American Sociological Review, 48(2): 147160.

Europlace. 2008. Rapport de la Comission Europlace: "Investissement Socialement Responsable" [Europlace Comission Report: "Socially Responsible Investment"]. Europlace Reports.

Eurosif. 2003. European SRI Study. Eurosif Studies.

Eurosif. 2008. European SRI Study. Eurosif Studies.

Fligstein, N. 1996. Markets as Politics: A Political-Cultural Approach to Market Institutions. American Sociological Review, 6 I (4): 656-673.

Fligstein, N. 200I. The Architecture of Markets. NJ: Princeton University Press.

Friedland, R. 2009. Institution, Practice and Ontology: Towards A Religious Sociology. In R. E. Meyer, K. Sahlin, M. J. Ventresca, \& P. Walgenbach (Eds.), Institutions and Ideology: Emerald.

Friedland, R., \& Alford, R. R. I99I. Bringing Society Back In: Symbols, Practices and Institutional Contradictions. In W. W. Powell, \& P. J. DiMaggio (Eds.), The New Institutionalism in Organizational Analysis: 232-263. Chicago: University of Chicago Press.

Gendron, C., \& Turcotte, M.-F. 2007. Les nouveaux mouvements sociaux économiques au coeur d'une nouvelle gouvernance [The New Economic Social Movements at the Heart of a New Governance]. Organisations \& Territoires, I6(I): 23-32.

Giamporcaro-Saunière, S. 2006. L'investissement socialement responsable entre l'offre et la demande: Analyse et enjeux de la construction d'une épargne politique [Socially Responsible Investment between Offer and Demand: Analysis and Stakes of the Building of a Political Saving]. René Descartes Paris V University Paris.

Goffman, E. 1974. Frame Analysis: An Essay on the Organization of the Experience. New York: Harper Colophon.

Gond, J.-P. 2006. Construire la Relation (Positive) entre Performance Sociétale et Performance Financière: de la Performativité à l'Autoréalisation? [Building the (Positive) Relationship between Societal Performance and Financial Performance: from Performativity to Selfrealization?]. Revue d'Economie Financière, 85: 63-79. 
Goodrick, E. 2002. Institutional Change and Healthcare Organizations: From Professional Dominance to Managed Care - Book Review. Administrative Science Quartely, 47(2): 384387.

Habermas, J. 1976. Legitimation Crisis (T. McCarthy, Trans.). London: Heinemann Educational Books.

Habermas, J. 1996. Between Facts and Norms. Cambridge (MA): MIT Press.

Habermas, J. 1998. Three Normative Models of Democracy. Constellations - An International Journal of Critical and Democratic Theory, I(I): I-I0.

Habermas, J. 2008. Between Naturalism and Religion: Philosophical Essays: Polity Press.

Langley, A. 1999. Strategies for Theorizing from Process Data. Academy of Management Review, 24: 69I-7I0.

Louche, C. 2004. Ethical Investment: Processes and Mechanisms of Institutionalisation in the Netherlands. In T. Mayer, \& J. Muchielli (Eds.), Multinational firms' location and the new economic geography (Diss. Doct. Erasmus Universiteit Rotterdam)

Louche, C., \& Lydenberg, S. D. 2006. Investissement Socialement Responsable: Différences entre Europe et Etats-Unis [Socially Responsible Investment: Differences Between Europe and the United-States]. Revue d'Economie Financière, 85(I-25).

Lounsbury, M. 2005. Institutional Variation in the Evolution of Social Movements - Competing logics and the Spread of Recycling Advocacy Groups. In G. F. Davis, R. W. Scott, \& M. N. Zald (Eds.), Social Movements and Organization Theory: Cambridge University Press.

Lounsbury, M., Ventresca, M. J., \& Hirsch, P. M. 2003. Social Movements, Field Frames and Industry Emergence: A Cultural-Political Perspective on US Recycling. Socio-Economic Review, I: 7I-104.

McAdam, D., \& Scott, R. W. 2005. Organizations and Movements. In G. F. Davis, D. McAdam, R. W. Scott, \& M. N. Zald (Eds.), Social Movements and Organization Theory: 4-40. New York: Cambridge University Press.

McAdam, D., Zald, M. N., \& McCarthy, J. D. 1996. Introduction: Opportunities, Mobilizing Structures and Framing Processes - Toward a Synthetic, Comparative Perspective on Social Movements. In D. McAdam, J. D. McCarthy, \& M. N. Zald (Eds.), Comparative perspectives on social movement: I-20. New York: Cambridge University Press. 
McCammon, H. H., Campbell, K. E., Granberg, E. M., \& Mowery, C. 200 I. How Movements Win: Gendered Opportunity Structures and U.S. Women's Suffrage Movements. American Sociological Review, 66(I): 49-70.

Meyer, D. S., \& Tarrow, S. G. 1998. The Social Movement Society. Lanham (MD): Rowman \& Littlefield.

Morris, D. A. 1994. Birmingham Confrontation Reconsidered: An Analysis of the Dynamics and Tactics of Mobilization. American Sociological Review, 58: 621-636.

Novethic. 2006. Le Marché français de I'ISR en 2005: encours et modalités de la gestion collective et dédiée [The French SRI Market in 2005: Assets and Forms of Collective Funds and Individual Mandates]. Etudes Novethic.

Novethic. 20I0. Intégration des enjeux ESG: Quelles pratiques pour quels objectifs? [Integration of ESG Criteria: Which Practices for Which Purposes?]. Etudes Novethic.

Penalva-Icher, E. 2007. Réseaux et régulation d'un marché financier "socialement responsable": en attendant la concurrence [Networks and Regulation of a Financial Market 'Socially Responsible': Waiting for the Competition]. Lille I University Lille.

Rao, H., Monin, P., \& Durand, R. 2003. Institutional Change in Toque Ville: Nouvelle Cuisine as an Identity Movement in French Gastronomy. American Journal of Sociology, 108(4): 795843.

Rao, H., Morrill, C., \& Zald, M. N. 2000. Power Plays: How Social Movements and Collective Action Create New Organizational Forms. Research in Organizational Behavior, 22: 237281.

Robecco, \& Booz. 2008. Responsible Investing: a Paradigm Shift From Niche to Mainstream. Robecco and Booz \& Company Studies.

Sakuma, K., \& Louche, C. 2008. Socially Responsible investment in Japan: its Mechanism and Drivers. Journal of Business Ethics, 82(2): 425-448.

Sandberg, J., Juravle, C., Hedesstrom, T. M., \& Hamilton, I. 2009. The Heterogeneity of Socially Responsible Investment. Journal of Business Ethics, 87: 519-533.

Scherer, A., \& Palazzo, G. 2007. Toward a Political Conception of Corporate Responsibility: Business and Society Seen from an Habermasian Perspective. Academy of Management Review, 32(4): 1096-1 I 20. 
Scott, R. W., Ruef, M., Mendel, P. J., \& Caronna, C. A. 2000. Institutional Change and Healthcare Organizations: From Professional Dominance to Managed Care. Chicago: University of Chicago Press.

Sjostrom, E. 2007. Translating Ideologically Based Concerns: How Civil Society Organisations Use the Financial Market to Protect Human Rights. International Journal of Environmental and Sustainable Development, 6(2): 157-173.

Strauss, A. C., \& Corbin, J. 1998. Basics of Qualitative Research: Techniques and Procedures for Developing Grounded Theory (Second ed.). CA: Thousand Oaks: Sage.

Thornton, P. H., \& Ocasio, W. 1999. Institutional Logics and the Historical Contingency of Power in Organizations: Executive Succession in the Higher Education Publishing Industry, 1958-1990. American Journal of Sociology, 105(3): 80 I-843.

Touraine, A. 1969. La société post-industrielle [The Post-Industrial Society]. Paris: Denoel-Gonthier.

Vogel, D. 2005. The Market for Virtue - The Potential and Limits of Corporate Social Responsibility: Brookings Institution Press.

Zald, M. N., \& Berger, P. L. 1978. Social Movements in Organizations: Coup d'Etat, Insurgency, and Mass Movements. American Journal of Sociology, 83: 823-86I.

Zald, M. N., \& McCarthy, J. D. 1977. Resource Mobilization and Social Movements: A Partial Theory. American Journal of Sociology, 82: I I I2-I I4I.

Zarlowski, P. 2007. Marketing Corporate Social Responsibility in a National Context: the Case of Social Rating Agencies in France. In F. Hond, G. A. d. Bakker, \& P. Neergard (Eds.), Managing Corporate Social Responsibility in Action - Talking, Doing and Measuring: 205-226. Aldershot (UK): Ashgate Publishing.

Zouati, P. 2009. Investir "responsable" - En quête de nouvelles valeurs pour la finance [Investing 'Responsibly': Looking for New Values for Finance]: Lignes de Repères. 


\section{APPENDIX I - LIST OF INTERVIEWEES}

\section{Organization}

Function

Date

Tim Recorde

e d

\section{CHALLENGERS}

\section{Asset Management Companies}

I Asset Management

Head of SRI

Company A

2 Asset Management

Company B

3 Asset Management

Company $\mathrm{C}$

4 Asset Management

Company D

5 Asset Management

Company D

6 Asset Management

Company D
Head of SRI

Head of SRI

SRI Analyst

Asset Manager

Project Managers (2)
$10 / 13 / 0$ Ih00 No

6

I3/II/0 IhI3 Yes

7

$0 \mathrm{I} / 08 / 0$ IhI5 Yes

7

06/09/0 Ihl0 Yes

8

09/03/0 0h45 Yes

9

19/03/0 0h59 Yes

9

\section{CIES Certification Committee (SRI Trade Unions' label)}

7 ClES Trade Union B Member

8 CIES Trade Union A

Member

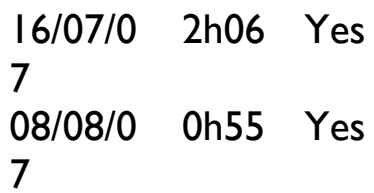

16/07/0 2h06 Yes

08/08/0 0h55 Yes

7

NGO

9 NGO A specialized in SRI Head of SRI Research

$30 / 10 / 0 \quad 0 h 50 \quad$ Yes

8

Social Rating Agencies

10 Social Rating Agency A Head of Research

I Social Rating Agency B Head of Research

12 Social Rating Agency C Head of Research

I3 Social Rating Agency D Head of Research
I2/I2/0 Ih22 Yes

7

02/08/0 0h45 Yes 7

09/08/0 Ih05 Yes

7

19/09/0 Ih00 Yes 

14 Social Rating Agency E
Client Relationship
Manager
8
26/09/0 Ih52 Yes
8

\section{Others}

15 Think Tank A specialized Project Manager in SRI

$17 / 07 / 0$ Ih29 Yes

7

\section{INCUMBENTS}

\section{Asset Management Companies}

I Asset Management

Company $\mathrm{E}$

2 Asset Management

Company D

3 Asset Management

Company D
CEO Europe \& CEO

France

Asset Manager

CEO

$\begin{array}{lll}05 / 02 / 0 & \text { Ih00 } & \text { Yes } \\ 9 & & \\ 09 / 03 / 0 & 0 h 45 & \text { Yes } \\ 9 & & \end{array}$

I3/03/0 Ih55 Yes

9

Financial institutions which have adopted an SRI approach for a part of their investments

4 Bank A

5 Insurance Company A

6 Insurance Company B

7 Bank B

8 Insurance Company A

9 Insurance Company B
Head of Corporate CSR $\quad 09 / 08 / 0 \quad$ Ih02 Yes

7

Head of Corporate CSR

26/10/0 2h00 Yes

7

CSR Group / Project

Managers (2)

CSR Project Manager

CSR Project Manager

CSR France / Project

Manager
19/02/0 Ih22 Yes

8

28/02/0 Ih27 Yes

8

II/03/0 Ih52 Yes

8

09/06/0 Ih05 Yes

8

\section{Brokers with SRI Departments}

10 Broker A

II Broker B
Head of SRI Research

Head of SRI Research
$21 / 11 / 0$ IhI3 Yes

7

23/02/0 Ih05 No

9

Consultants specialized with a practice specialized in SRI 
12 Consulting Firm A

13 Consulting Firm B

14 Consulting Firm C
Senior Consultant

Consultant

Partner
09/07/0 lh30 No

7

25/02/0 Ih00 No

8

05/03/0 Ih00 Yes

8

French Asset Management Professional Association

15 French Association of Chief Executive Officer 23/07/0 Ih35 Yes Management

7

16 French Association of Management

Head of Research

$22 / 10 / 0 \quad 2 h / 5 \quad$ No

7

NGO

17 NGO B specialized in Finance

Project Manager

06/03/0 2h03 Yes

Pension Fund

18 Pension Fund $\mathrm{A}$

Head of Equity and SRI

29/10/0 Ih07 Yes

8 
Figure I: Key Elements of Framing - French SRI Sector 1997-2009

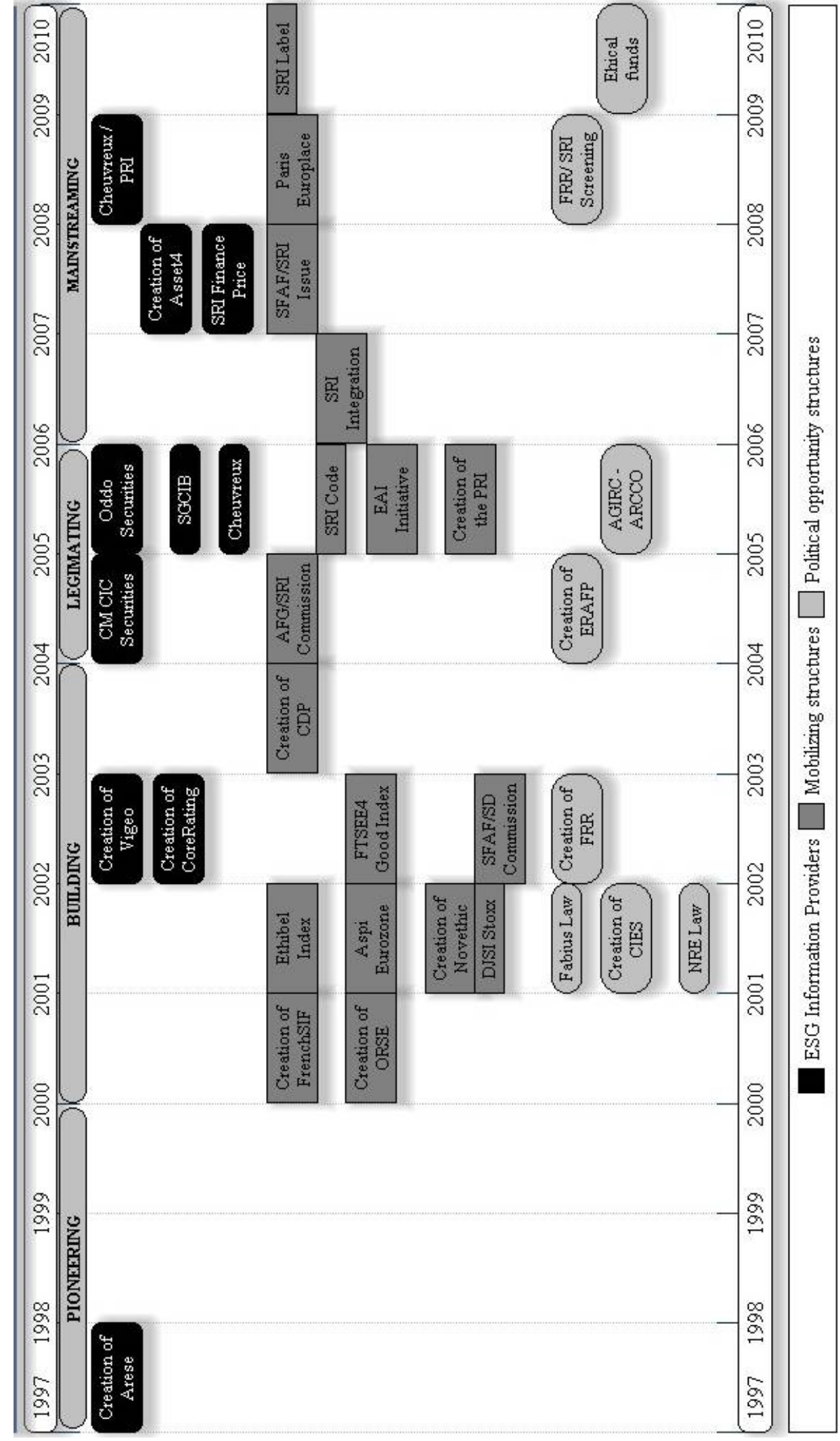




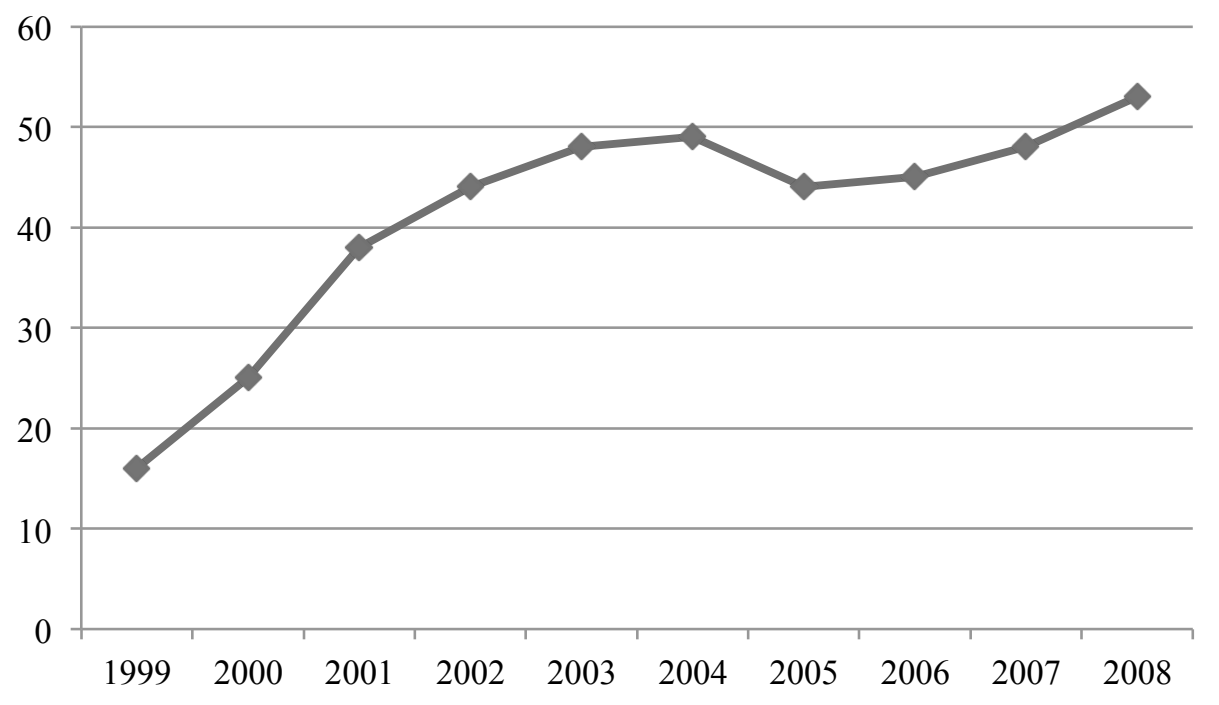

Figure 2: Number of Asset Management Companies Providing SRI Funds

Figure 3: Evolution of SRI and Conventional Assets (100 Points Base in 2000)

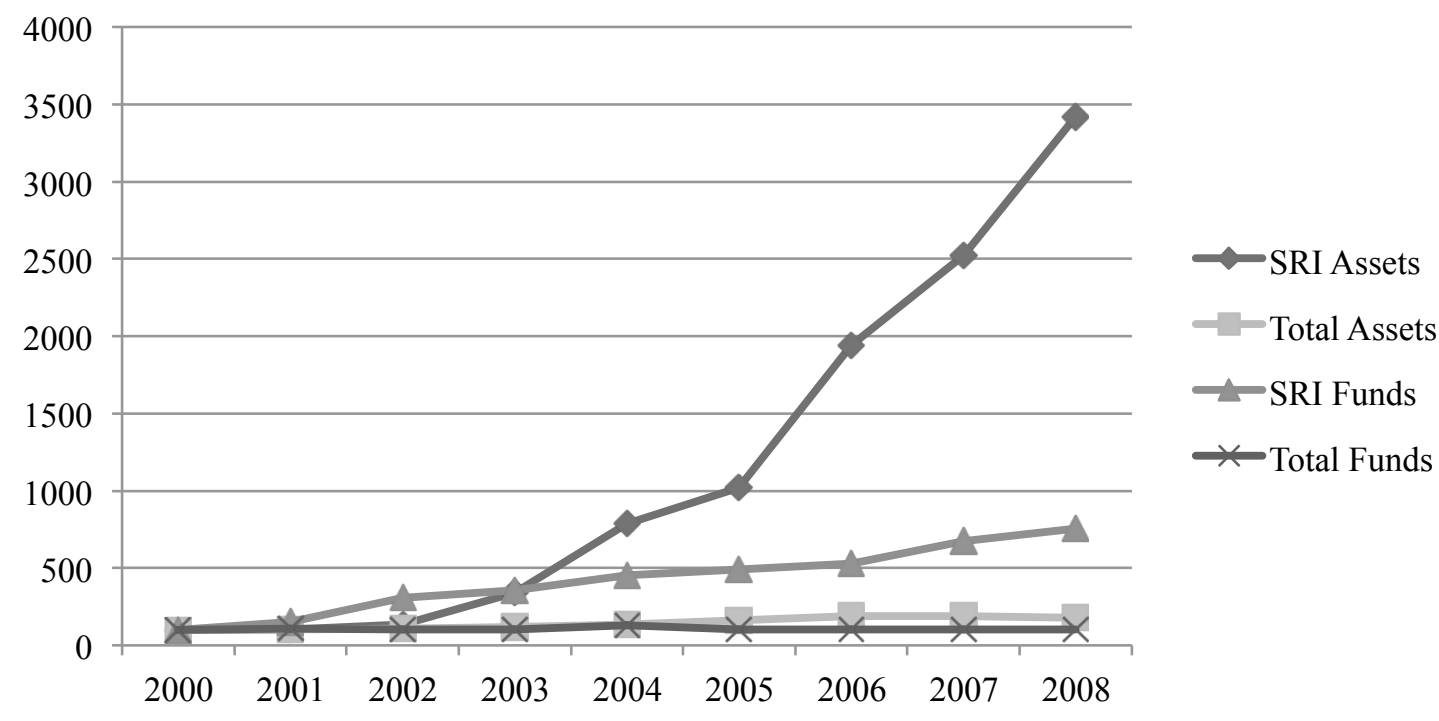


Figure 4: Number of Articles Mentioning SRI in French Newspapers

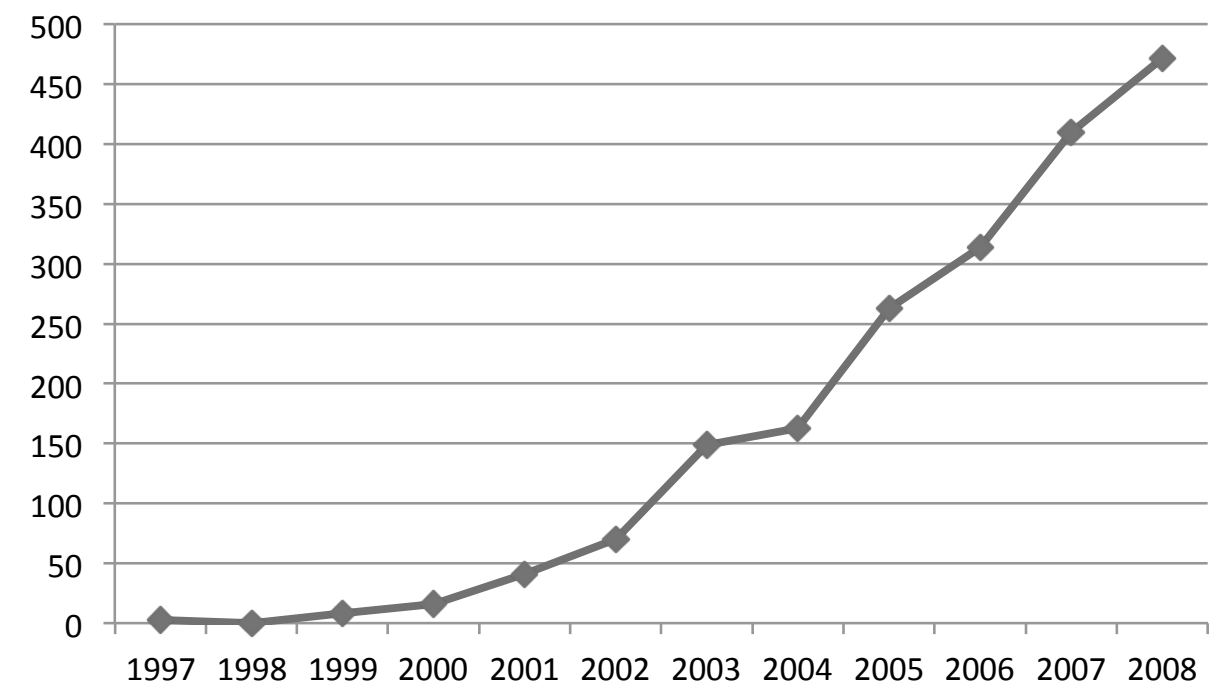

Figure 5: Number of SRI Analysts in Asset Management Companies

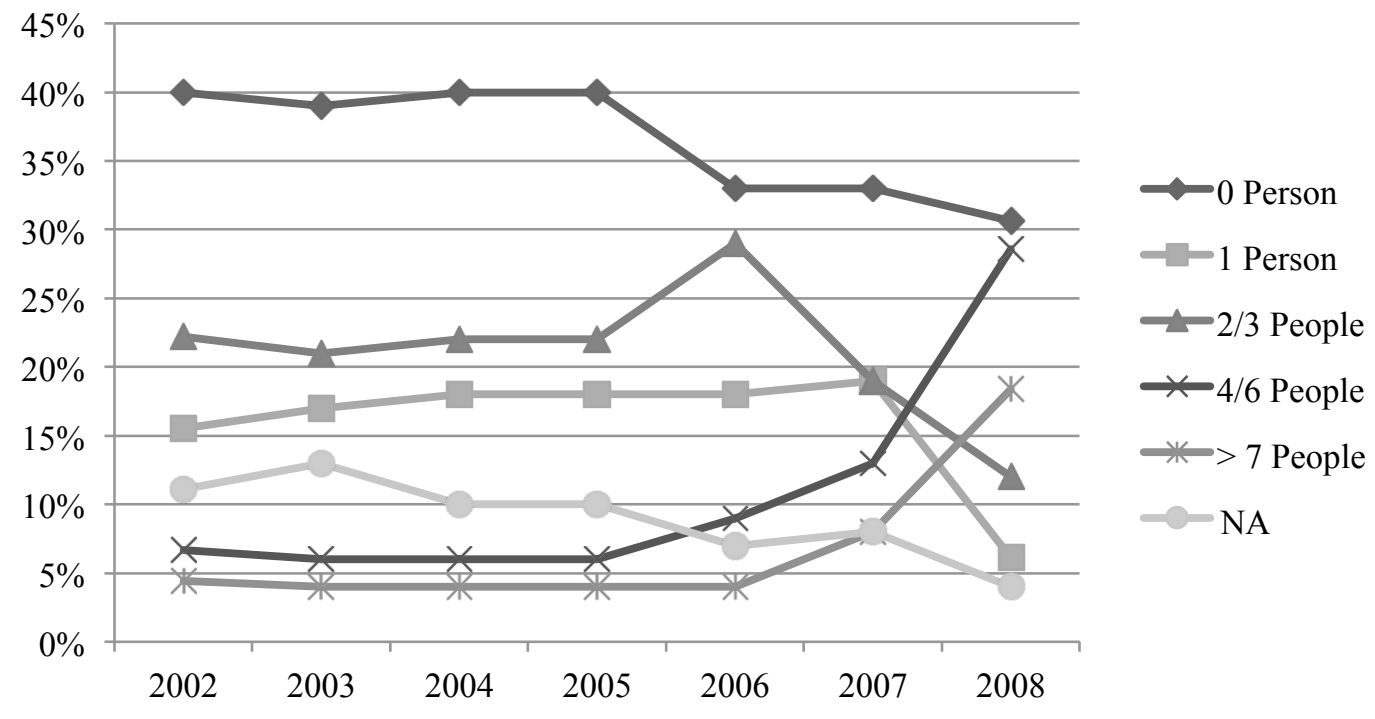




\section{Notes}

\footnotetext{
${ }^{1}$ Source: Principles for Responsible Investment (PRI) www.unpri.org

${ }^{2}$ French Securities Regulator

${ }^{3}$ Pension Reserve Fund

${ }^{4}$ Trade Unions Committee for Employee Saving Funds

${ }^{5}$ Study Center for Corporate Social Responsibility

${ }^{6}$ French Social Investment Forum

${ }^{7}$ French Society of Financial Analysts

${ }^{8}$ Source : Carbon Disclosure Project (CDP) www.cdproject.net

${ }^{9}$ French Public Service Additional Pension Scheme

${ }^{10}$ Source : ERAFP : www.rafp.fr

${ }^{11}$ 'General association of institutions specializing in private pension schemes for executives and employees.

${ }^{12}$ Total is said to be one of the more polluting companies in France.

${ }^{13}$ French Association of Asset Management

${ }^{14}$ Anisette is anise-flavored French liquor which is diluted with water before drinking, generally one volume of liquor to six volumes of water.

${ }^{15}$ Source: Principles for Responsible Investment (PRI) www.unpri.org

${ }^{16}$ This action follows the French 'Grenelle de 1'Environnement' (2008-2009), which established six working groups to address ways to redefine France's environment policy and proposed new laws.
}

\section{Acknowledgments}

The author wishes to thank participants in the 2009 PRI Conference, the 2009 EURAM Conference, participants in the 'Comparative Perspectives on Transnational Standards for Labour and Environment' Workshop of the Max Planck Institute for the Study of Societies (June 2009) and in the research seminars of Uppsala University (November 2008), Stockholm School of Economics (January 2009) and ESSEC Business School (May 2009), for their precious comments on earlier versions of this paper. More particularly, I am grateful to Katarina Buhr, Philippe Lorino, Nicolas Mottis, François Perrot, the editor of this Special Issue and the two anonymous reviewers for their helpful suggestions. Financial support from the Ecole Polytechnique Chairs in Business Economics and Sustainable Finance and Responsible Investment is acknowledged. 
